\title{
SLRA: Challenges faced by SMEs in the adoption of E-commerce and sustainability in Industry 4.0.
}

\author{
Asmat Ara Shaikh, Amir Nasir Patel, M. Z. Shaikh, C. R.Chavan
}

\begin{abstract}
The ultimate goal of this article is to delve into and identify the key elements that influence e-business implementation in both "ERP-enabled and non-ERP-enabled" businesses. To comprehensively examine the factors that drive e-business acceptance and to fully articulate the significant intrinsic abilities and traits required to effortlessly convert the organization from brick-and-mortar to click-and-mortar through e-commerce. As the world moves toward technology 5.0, SMEs are unable to thrive in "I-4.0." The COVID-19 epidemic has undoubtedly proven to the world the value of sustainable technology in empowering distant employees.

And a very few relative handfuls of literature review-based research have tested the ideas of the "Technology-Organisation-Environment (TOE) framework, Diffusion of Innovation (DOI) theory, and Resource-Based View (RBV) theory", in combination. Furthermore, the comparative study contributes by proposing the profound significance of E-commerce as a mediator variable amongst essential TOE, DOI, and RBV characteristics and company success. The successful adoption and effective use of e-commerce are critical to progressively increasing potential productivity in the digital age. This exploratory research has successful applicability since it employs the "TOE, DOI, and RBV theories" that are appropriate for the implementation of E-commerce and, as a result, contribute to enhancing the efficiency of Indian small and medium companies.
\end{abstract}

Keywords: SME’s, E-commerce adoption challenges, Industry 4.0, Sustainability.

JEL Code- M150, M210, M310

\section{INTRODUCTION}

In the present era of digitization, the evolving phenomena of E-commerce are rapidly developing, predominantly in developing economies, and firms are beginning to willingly choose to purchase and trade online. The emerging world's two most important economies, India and China, are diversifying their activities from traditional enterprises to click-and-mortar daily. The economic development of the Indian E-commerce market is undoubtedly expected to achieve 64 billion US dollars by the end of this decade (Dutta, Mishra, Khandelwal, \& and Katthawala, 2020).

Similarly, China's internet commerce market figures show that the developed country has indeed obtained a 574 billion US \$ market in 2018 (Lu, Yang, Liu, \& and Jia, 2020). In the same way, the rapid growth of the e-commerce market is revolutionizing the way companies function in both major and small enterprises (Ozturk, 2016). Nevertheless, E-commerce adoption in small and medium-sized businesses (SMEs) has substantially enlarged and is continuing to grow tremendously. SMEs are increasing the sustainability and considerable

Dr. Asmat Ara Shaikh, Bharati Vidyapeeth's Institute of Management Studies and Research, Navi Mumbai, e-mail: asmatarakhan111@gmail.com

Mr. Amir Nasir Patel, Wishup, e-mail: amir.patel@wishup.co

Dr. M. Z. Shaikh, Shri Vile Parle Kelvani Mandal’s, Shri Bhagubhai Mafatlal Polytechnic, (Govt. Aided Autonomous Institute), Mumbai, e-mail: mzshaikh2003@yahoo.co.in

Dr. C. R. Chavan, Professor, Jamnalal Bajaj Institute of Management Studies, Dept. of Mumbai University, e-mail: chandrahauns@gmail.com 
progress of many expanding economies across the world in the twenty-first century.

According to the "Asia Pacific Economic Report", SMEs add to more than half of all employment and more than 97 percent of all enterprises in "Asia-Pacific Economic Cooperation (APEC) economies” (Asia Pacific Economic Coorporation Report, 2018). Furthermore, the outstanding stake of APEC countries' GDP contributed by SMEs ranges from $20 \%$ to $50 \%$. Likewise, in the "Association of Southeast Asian Nations (ASEAN)" SMEs are accountable for 63.3 percent of employment and 42.2 percent of the net investment (ASEAN. SME Policy Index; OECD/ERIA: Jakarta, 2020). Equivalently, (Zafar \& and Mustafa, 2017) stated that, on aggregate, in underdeveloped nations, SMEs provide around $70 \%$ of employment and $60 \%$ of GDP. Furthermore, in developing nations, SMEs are liable for $95 \%$ of employment and $70 \%$ of GDP. As a result, it is demonstrated that SMEs are correspondingly significant for every economy around the globe.

\section{Objective}

Are SME's (Small and Medium-Sized Enterprises) Ready for Industry 4.0?

The primary objective of the proposed article is to precisely ascertain the key challenges that SMEs encounter while adopting E-commerce for long-term sustainability in Industry 4.0.

\section{Background to the study}

According to the reviewed research, two ideas could represent essential theoretical approaches for the comprehensive report of circumstantial elements. The original key concept is the "Diffusion Of Innovation (DOI)", which adequately provides a vital framework for exploring the diffusion of innovative technologies (Hsu, Kraemer, \& and Dunkle, 2006)

According to DOI theory, innovation features and organizational factors accurately determine a company's acceptance and successful implementation of key innovations. According to Rogers, innovation features are composed of five aspects (Ref. Fig.1(a)), authors proposed that numerous organizational features (Ref. Fig.2(a)) affect the acceptance and application of breakthroughs at the organizational level. The "Technology-OrganizationEnvironment (TOE) framework", originally taken from the "DOI" concept, is the second theoretical approach. The comprehensive TOE framework highlights three contributing factors that may positively impact an organization's use of technical innovation (Ref. Fig.1(b)): (1) The technical feasibility positively identifies the current technologies in practical use and the pertinent technical expertise obtainable in an organization. (2) The organizational design states to in-house organizational gauges like the size. And (3) the environmental context represents the peripheral realm in which an enterprise operates - its businesses, recent entrants, and business associates.

The "TOE framework" and the "DOI theory" intersect in many possible ways. There are apt analogies between the unique features of key innovation and the technical setting, as well as between the qualities of organizations and the organizational milieu. There are, however, some significant discrepancies between the two prevailing philosophies. Inapt comparison to the DOI theory, the "TOE framework" does not attribute the active participation of personality traits like organizational support. Similarly, unlike the TOE framework, the DOI theory does not take into account the profound effect of environmental factors. More initial studies on e-business adoption have highlighted the importance of including TOE situations to reinforce the DOI theories (Hsu, Kraemer, \& and Dunkle, 2006). 
Fig. 1 DOI (a) and TOE (b) framework

\section{DOI theory}

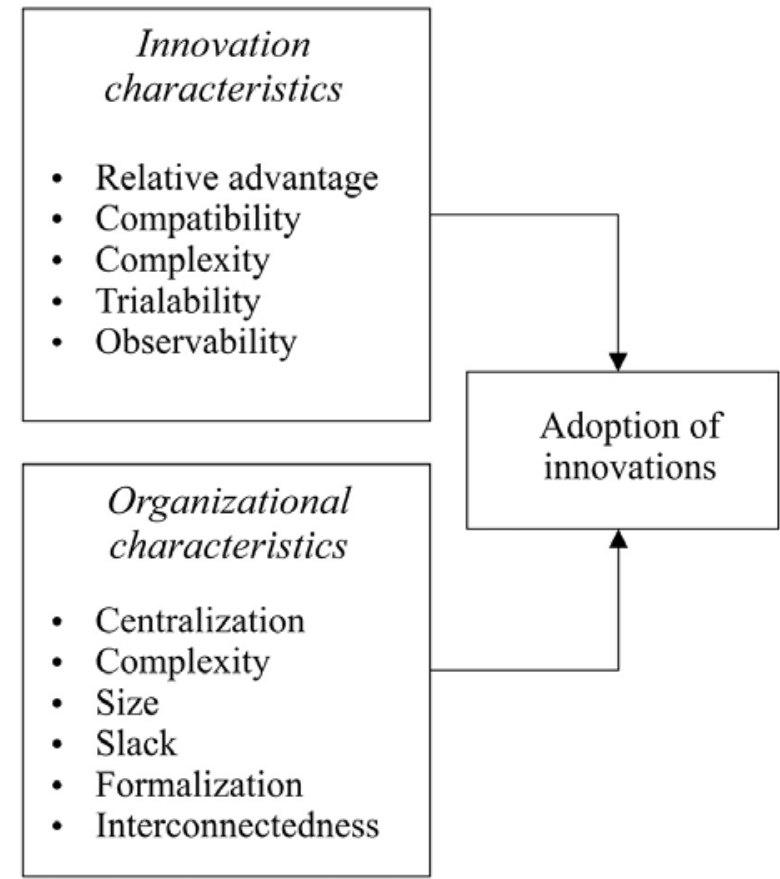

TOE theory

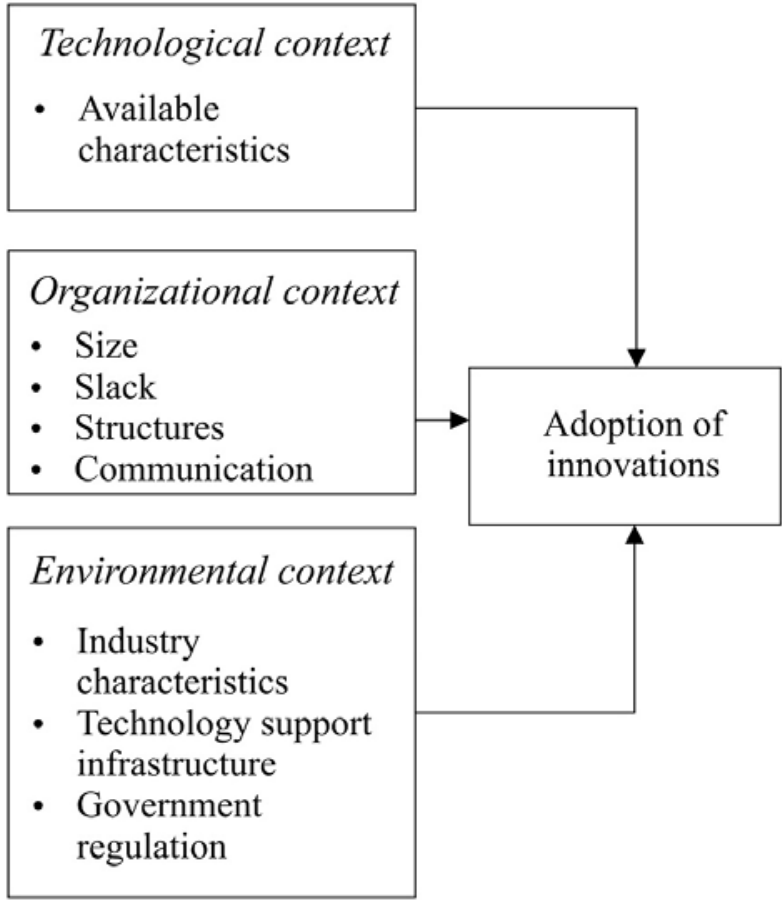

Source: (Hsu, Kraemer, \& and Dunkle, 2006)

\section{E-business adaptation and practice perspective}

Although E-business deployment has been thoroughly researched in the earlier studies its reality does not diminish with considerable epoch. Peer-reviewed experimental articles on ebusiness uptake and extensive applications are invariably found and emphasized in IT acceptance studies to ensure this compelling argument. Only research articles that smear "DOI and/or TOE" techniques are sufficiently shown in the pursuit of scholarly databases to reduce the search for relevant significant contributions. The "TOE framework and the DOI theory" have been instantly discovered to be widely employed frameworks in the evaluation of Ebusiness implementation (Banerjee, Wei, \& and Ma, 2012). Experiential studies on E-business deployment seek to adequately demonstrate the diverse ramifications of E-business espousal based on the technology adoption of the enterprises included. The experiential research on Ebusiness applications seeks to highlight the potential benefits of E-business and the possible consequences for e-business advancement. Initial research on E-business implementation demonstrated it is not a phenomenon owned by big enterprises in European industrialized nations. (Zhu, Kraemer, \& and Xu, 2003). E-business impact is assessed by three primary actions throughout the value chain, according to (Zhu, Kraemer, \& and Xu, 2003) downstream sales, upfront procuring, and operational processes demonstrated that, while both front-head and back-end abilities deliver a significant contribution to E-business value, back-end collaboration exercises a significantly more considerable influence.

Digital disruption is becoming extremely significant in SMEs, and the prospective intensity of technological uptake has risen rapidly since COVID-19. It is past time for SMEs' proprietors and sustainable utilization to adequately incorporate innovative technology enthusiastically; they can no longer support fiercely resist it (Asmat, Anuj, Asif, \& Zafar, 2021). Scientifically derived from the previous explanation, a human resource department that effectively leverages self-confidence in active recruitment, training, cooperation, and policy formation may powerfully aid enterprises in meeting the current COVID-19 difficulties (Ayedee, Anuj, \& Asmat, 2021).To satisfactorily accomplish targeted goals and to fulfil the demands of teams, suppliers and distributors, consumers, and substantial concerned citizens to transmit specific 
disparities throughout epidemics, a progressive changeover can be properly developed (Asmat \& Mohd, A VIEWPOINT ON SUSTAINABLE PRACTICES OF COLES AND WOOLWORTHS DURING COVID-19, 2021). Furthermore, (Hsu, Kraemer, \& and Dunkle, 2006) contend that the most considerable value of e-business is obtained when numerous supply chain members use it, but (Lin \& and Lin, Determinants of e-business diffusion: A test of the technology diffusion perspective., 2008) discovered that internal communication is crucial for meaningfully improving e-business productivity. Along with TOE and DOI theories, asset perspective (RBV) is used in many technologies' usage/adoption research. RBV is used as the grounding theory in this investigation. The fundamental point of the RBV theory is resource heterogeneity, which invariably refers to the firm's capacities, various resources, and immobility (Mata, Fuerst, \& and Barney, 1995).

These distinct resources possess qualities such as being economically valued, comparatively rare, hard to replicate by adversaries, and non-replaceable by other market participants. Organizations safeguard distinct assets that they utilize efficiently and effectively to achieve a competing edge (Hwang \& and Min, 2015). Furthermore, very few researchers have adequately investigated the organizational and environmental elements of the TOE model in conjunction with "DOI and RBV theories". As a result, the emphasized conceptual and technical concerns warrant further investigation, and this work adds to current knowledge by addressing the research questions in developing nations (Depietro, Wiarda, \& Fleischer, 1990)

Fig. 2 Resource Based View

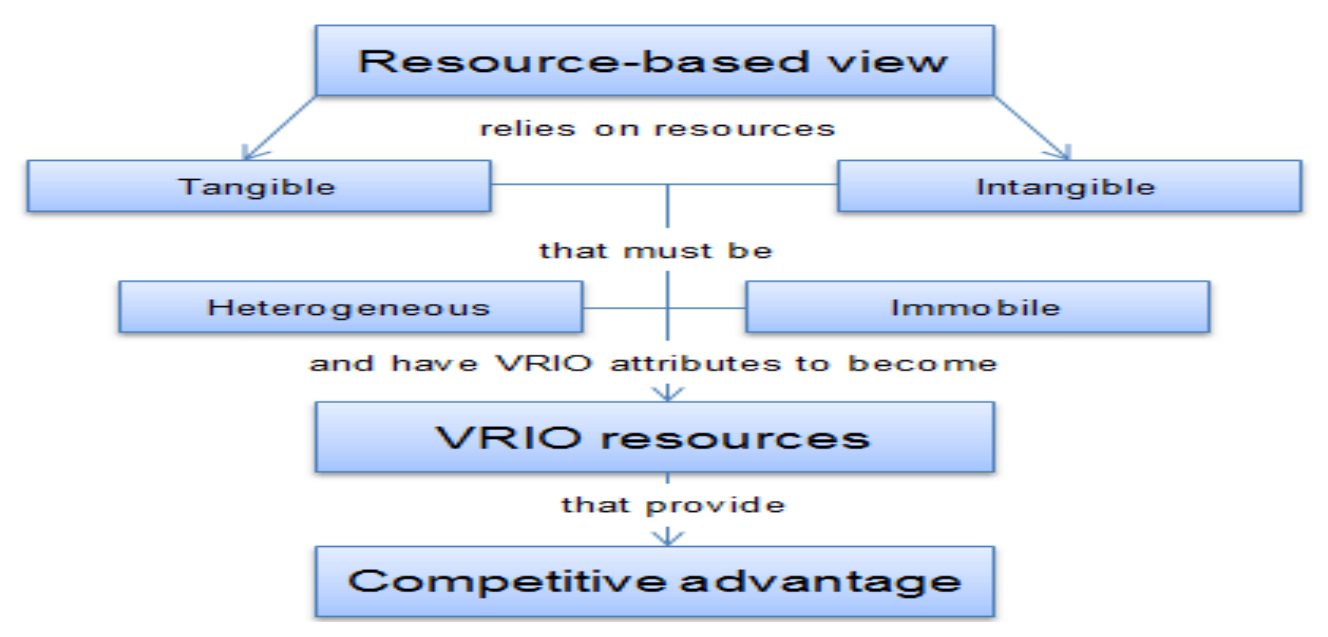

Source: (Rothaermel, 2013) 
Is the Resource or Capability...

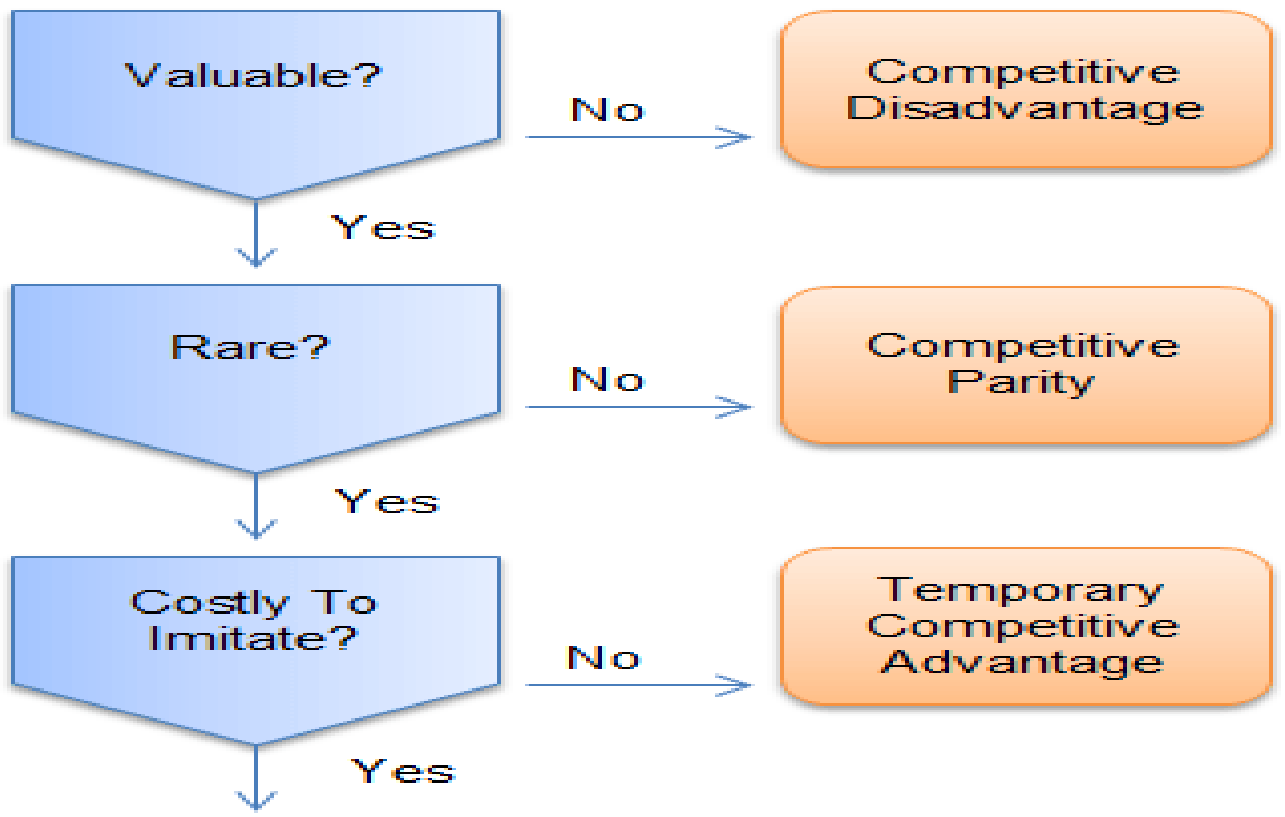

and is the Firrta...

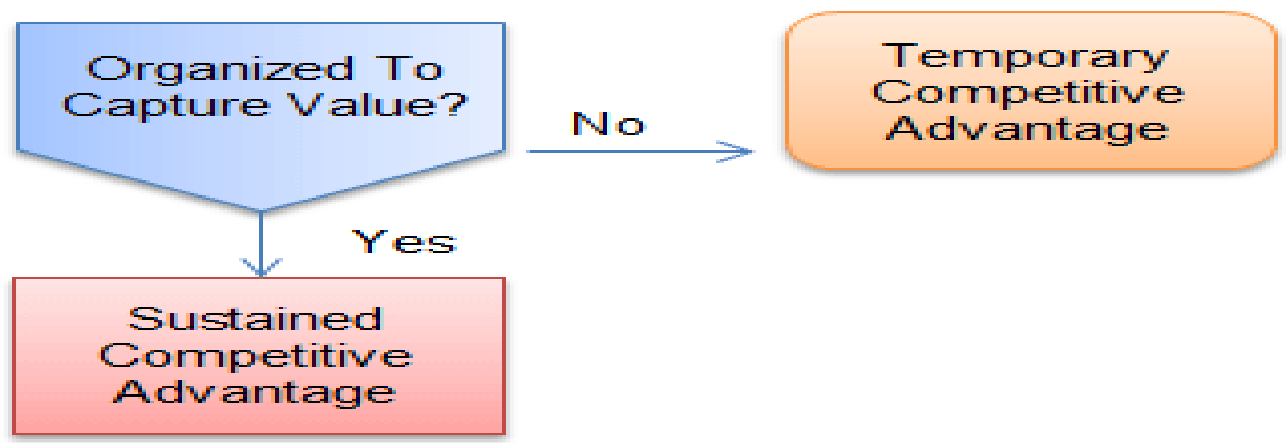

Fig. 3 Resource or Capability

Source: (Rothaermel, 2013)

\section{METHODS}

This paper's delving technique is built on a Systematic Literature Review Analysis (SLRA) of scholarly research articles. A series of published research papers carefully outlining the key problems that SMEs experience when adopting E-commerce has been adequately evaluated in a transverse style. (Snyder, 2019) contended that a systematic literature review may be employed as a study approach. The investigators can efficiently conduct a structured review by meticulously constructing tables after methodically searching for illustrated papers in their subject domain (Paul \& and Bhukya, 2021). Through a proposed comprehensive study, the prominent authors methodically evaluated 50 published articles from the prior decade to adequately identify the common obstacles experienced by SMEs while embracing E-commerce. ProQuest, Absco, Elsevier, Google Scholar, and other repositories are prominently used to persistently seek research articles.

Before one decade $\mathbf{4 0}$ published articles include a description of the supporting theoretical background for this active investigation. First, the utmost pertinent theories on electronicbusiness implementation are satisfactorily established. A conceptual framework for E-business implementation must take into account the variables that impact the tendency to investigate, embrace, and enforce IT advancement; such variables are deeply embedded in particular technological innovation attributes as well as a particular organization's structural factors and environmental exposures (Lin, Understanding the determinants of electronic supply chain management system adoption: Using the technology-organization-environment framework., 2014). Subsequently, to thoughtfully provide the underlying principles for this extensive 
research, the e-business adaptation, and use viewpoint, as well as the settings of e-business adoption in developing nations, are discussed.

Table 1

\begin{tabular}{|c|c|c|c|}
\hline \multicolumn{4}{|c|}{ One Decade Literature Review } \\
\hline $\begin{array}{l}\text { Sr } \\
\text { No }\end{array}$ & Year & Author & E-commerce adoption challenges faced by SME's \\
\hline 1 & 2011 & (Good, 2011) & $\begin{array}{l}\text { Microentrepreneurs' access to products and services } \\
\text { may be hampered due to lack of financial support, } \\
\text { lack of operational infrastructure and/or a selection } \\
\text { of high-cost/low-benefit technological } \\
\text { products/services, lack expertise or are averse to } \\
\text { technology, as well as those who are inefficient in } \\
\text { terms of administration, may be less able to turn IT } \\
\text { into competencies than others. }\end{array}$ \\
\hline 2 & 2011 & $\begin{array}{l}\text { (Ghobakhloo, } \\
\text { 2011) }\end{array}$ & $\begin{array}{l}\text { Factors influencing EC adoption in SMEs include: } \\
\text { RBV- Perceived relative advantage, perceived } \\
\text { compatibility, and perceived competitiveness. } \\
\text { DOI- CEO ingenuity, information intensity } \\
\text { TOE- Technology vendor assistance. }\end{array}$ \\
\hline 3 & 2011 & (Bélanger, 2011) & $\begin{array}{l}\text { The author addressed how information privacy is a } \\
\text { significant issue influencing "E-commerce } \\
\text { adoption". }\end{array}$ \\
\hline 4 & 2012 & $\begin{array}{l}\text { (Bin, Yongyi, \& } \\
\text { Lei, 2012) }\end{array}$ & $\begin{array}{l}\text { SMEs' capability development faces three major } \\
\text { challenges: lack of resource availability and } \\
\text { accessibility, resource utilization capability, and } \\
\text { capability of utilizing and developing institutions. }\end{array}$ \\
\hline 5 & 2012 & $\begin{array}{l}\text { (Mwangi \& } \\
\text { Mwakaba, 2012) }\end{array}$ & $\begin{array}{l}\text { According to the author, the following are the } \\
\text { problems that African microenterprises face: } \\
\text { Affordability, limited Internet access, competition, a } \\
\text { complex procedure, and a lack of knowledge, lack of } \\
\text { Government support. }\end{array}$ \\
\hline 6 & 2012 & $\begin{array}{l}\text { (Banerjee, Wei, \& } \\
\text { and Ma, 2012) }\end{array}$ & $\begin{array}{l}\text { The author concludes following are the limitations to } \\
\text { the adoption of technology: } \\
\text { DOI- Observability, Complexity, and Compatibility }\end{array}$ \\
\hline
\end{tabular}


SLRA: Challenges faced by SMEs in the adoption of E-commerce and sustainability in Industry 4.0.

\begin{tabular}{|c|c|c|c|}
\hline 7 & 2012 & $\begin{array}{l}\text { (Eze, Duan, \& } \\
\text { Chen, 2012) }\end{array}$ & $\begin{array}{l}\text { Factors withholding SMEs to adopt E-commerce: } \\
\text { TOE: “Organization context- size, organization } \\
\text { readiness, top Management Support Environment } \\
\text { Technology Context- perceived direct Benefit, } \\
\text { perceived indirect benefit external pressure in the } \\
\text { context, E-market trust”. }\end{array}$ \\
\hline 8 & 2012 & (Zaied, 2012) & $\begin{array}{l}\text { "According to the study findings, the following are } \\
\text { the most significant hurdles to e-commerce } \\
\text { implementation: } \\
\text { Technological impediments, Legal and regulatory } \\
\text { hurdles, political barriers, Social and cultural } \\
\text { barriers, lack of internet security, limited usage of } \\
\text { Internet banking, expensive, government policy } \\
\text { changes, lack of e-commerce standards". }\end{array}$ \\
\hline 9 & 2013 & (OP, 2013) & $\begin{array}{l}\text { The preceding context demonstrates the major } \\
\text { variables influencing the adoption of technology e- } \\
\text { commerce: Organizational variables, Environmental } \\
\text { factors, technical factors. }\end{array}$ \\
\hline 10 & 2013 & (Kamal, 2013) & $\begin{array}{l}\text { Small firms confront the following challenges: } \\
\text { DOI: IT awareness, } \\
\text { TOE: Lack of infrastructure, lack of technical skills } \\
\text { RBV: Affordability }\end{array}$ \\
\hline 11 & 2013 & $\begin{array}{l}\text { (A.P \& C.T, } \\
\text { 2013) }\end{array}$ & $\begin{array}{l}\text { "The following are the most common challenges that } \\
\text { SMEs face:" } \\
\text { Low Internet speed; the dearth of the trained } \\
\text { workforce; the expense of employing and securing } \\
\text { expert IT personnel; the operating cost of Internet. }\end{array}$ \\
\hline 12 & 2013 & (Alzahrani, 2013) & $\begin{array}{l}\text { The following are the issues impeding e-commerce } \\
\text { adoption: }\end{array}$ \\
\hline
\end{tabular}




\begin{tabular}{|c|c|c|c|}
\hline & & & $\begin{array}{l}\text { DOI- “Perceived Privacy” and Customers Concerns } \\
\text { regarding security } \\
\text { TOE- “IT Systems, Accountable Business Practices, } \\
\text { Tangible Design, and Networked Infrastructure”. }\end{array}$ \\
\hline 13 & 2013 & (Larreina, 2013) & $\begin{array}{l}\text { Critical Factors Impeding E-Business Adoption in } \\
\text { Logistics Companies: } \\
\text { RBV- Expensive initial investment, budgetary } \\
\text { restrictions, and high operating and maintenance } \\
\text { costs. } \\
\text { Inadequate IT abilities, Uncertainty and danger, } \\
\text { Inadequate access to ICT consultant services Data } \\
\text { protection, incompatible Services. }\end{array}$ \\
\hline 14 & 2014 & $\begin{array}{l}\text { (Juhi \& Maryann, } \\
\text { 2014) }\end{array}$ & $\begin{array}{l}\text { Raising enough money and obtaining loans from } \\
\text { microfinance organizations and commercial banks } \\
\text { are among the challenges that Kenyan micro and } \\
\text { female entrepreneurs confront. Lack of financial } \\
\text { resource management expertise, inadequate } \\
\text { management, gender inequalities, complex } \\
\text { registration processes and excessive levies imposed, } \\
\text { and a lack of marketing information. }\end{array}$ \\
\hline 15 & 2014 & $\begin{array}{l}\text { (M.E \& J.P, } \\
\text { Drivers and } \\
\text { inhibitors to e- } \\
\text { Commerce } \\
\text { adoption among } \\
\text { SMEs in Nigeria, } \\
\text { 2014) }\end{array}$ & $\begin{array}{l}\text { One significant barrier to e-commerce adoption is a } \\
\text { lack of awareness of its enormous potential. } \\
\text { Furthermore, insufficient skill investment and the } \\
\text { relatively high initial costs of establishing e- } \\
\text { commerce strategies all serve as solid foundations } \\
\text { for non-use. }\end{array}$ \\
\hline 16 & 2014 & (D.O, 2014) & $\begin{array}{l}\text { Based on the data, the study found that, despite SSE } \\
\text { owners' high computer literacy and personal } \\
\text { computer usage, the degree of e-commerce adoption } \\
\text { in the Nigeria retail sector is relatively low due to the } \\
\text { following factors: } \\
\text { - Energy, electricity, and capital shortages; e- } \\
\text { commerce security issues; and a lack of a } \\
\text { developed/effective legal and regulatory structure. }\end{array}$ \\
\hline
\end{tabular}


SLRA: Challenges faced by SMEs in the adoption of E-commerce and sustainability in Industry 4.0.

\begin{tabular}{|c|c|c|c|}
\hline 17 & 2014 & $\begin{array}{l}\text { (Lin, } \\
\text { Understanding the } \\
\text { determinants of } \\
\text { electronic supply } \\
\text { chain } \\
\text { management } \\
\text { system adoption: } \\
\text { Using the } \\
\text { technology- } \\
\text { organization- } \\
\text { environment } \\
\text { framework., } \\
\text { 2014) }\end{array}$ & $\begin{array}{l}\text { "The following factors have a significant impact on } \\
\text { the adoption of supply chain management systems": } \\
\text { TOE: } \\
\text { "Benefits Perceived and incurred costs in the } \\
\text { technological context } \\
\text { Firm size, top management support, and absorptive } \\
\text { ability are examples of organizational context. } \\
\text { Environmental context- Influence of trading } \\
\text { partners, Competitive pressure”. }\end{array}$ \\
\hline 18 & 2015 & (Pendse, 2015) & $\begin{array}{l}\text { The following are the challenges that the SMEs faces } \\
\text { in terms of IT adoption: } \\
\text { Inadequate IT knowledge, Finances, and } \\
\text { affordability are dependent on the availability of } \\
\text { trained workers. } \\
\text { Lack of infrastructure, Inadequate recognition of the } \\
\text { operational issue. }\end{array}$ \\
\hline 19 & 2015 & (Saha, 2015) & $\begin{array}{l}\text { The following remain the issues that SMEs } \\
\text { encounter when it comes to IT adoption: } \\
\text { Insufficient IT expertise, Funds, and affordability are } \\
\text { dependent on the presence of skilled professionals, } \\
\text { and insufficient infrastructure, and an inability to } \\
\text { recognize technical challenges. }\end{array}$ \\
\hline 20 & 2015 & (Mbinda, 2015) & $\begin{array}{l}\text { The following are the obstacles that SMEs face: } \\
\text { Financial assistance, a lack of government } \\
\text { assistance, a labor shortage, insufficient } \\
\text { infrastructure, and a lack of access to technology are } \\
\text { all issues that must be addressed. Inadequate } \\
\text { awareness. }\end{array}$ \\
\hline
\end{tabular}




\begin{tabular}{|c|c|c|c|}
\hline 21 & 2015 & $\begin{array}{l}\text { (M.E \& J.P, } \\
\text { 2015) }\end{array}$ & $\begin{array}{l}\text { The study's findings indicated the following hurdles } \\
\text { to E-commerce adoption: } \\
\text { Limited knowledge of the entire range of advantages } \\
\text { of electronic commerce, Lack of awareness of its } \\
\text { huge potential, Insufficient talent investment, High } \\
\text { initial expenses of developing e-commerce } \\
\text { strategies. }\end{array}$ \\
\hline 22 & 2015 & (Pendse, 2015) & $\begin{array}{l}\text { The following are the challenges that the SMEs faces } \\
\text { in terms of IT adoption: } \\
\text { Inadequate IT knowledge, Finances, and } \\
\text { affordability are dependent on the availability of } \\
\text { skilled labor, Accessibility, Infrastructure, } \\
\text { Inadequate recognition of the organizational problem }\end{array}$ \\
\hline 23 & 2016 & $\begin{array}{l}\text { (Ahmad \& Sinha, } \\
\text { 2016) }\end{array}$ & $\begin{array}{l}\text { "Barriers to SMEs entering e-commerce are as } \\
\text { follows: } \\
\text { Lack of awareness, knowledge of e-commerce, trust } \\
\text { and confidence issues, legal and regulatory } \\
\text { framework, poor infrastructure access, Concerns } \\
\text { about security, high costs. }\end{array}$ \\
\hline 24 & 2016 & $\begin{array}{l}\text { (Hussein \& } \\
\text { Baharudin, 2016) }\end{array}$ & $\begin{array}{l}\text { According to the author, the following are the } \\
\text { challenges that SMEs face when it comes to IT } \\
\text { adoption: } \\
\text { Intention/Continued Adoption of E-Commerce } \\
\text { Compatibility, Pressure from Competitors, } \\
\text { Organizational Security Support. }\end{array}$ \\
\hline 25 & 2016 & (Abualrob, 2016) & $\begin{array}{l}\text { The author cites the following hurdles to technology } \\
\text { adoption: } \\
\text { TOE- “External Barriers: Government Instability, } \\
\text { Occupation Restrictions, and Logistics Difficulties” } \\
\text { DOI- “Internal Barriers: Perceived Losses, } \\
\text { Uncertainty, and Complexity”. }\end{array}$ \\
\hline
\end{tabular}


SLRA: Challenges faced by SMEs in the adoption of E-commerce and sustainability in Industry 4.0.

\begin{tabular}{|c|c|c|c|}
\hline 26 & 2016 & $\begin{array}{l}\text { (Chatzoglou, } \\
\text { Fragidis, } \\
\text { Chatzoudes, \& } \\
\text { Symeonidis, } \\
\text { 2016) }\end{array}$ & $\begin{array}{l}\text { "Independent factors affecting the adoption of E- } \\
\text { commerce": } \\
\text { TOE: } \\
\text { IT infrastructure and Internet skills are examples of } \\
\text { technological context. } \\
\text { Firm size, firm scope, CEO expertise, and adoption } \\
\text { cost are all factors to consider in the organizational } \\
\text { environment. } \\
\text { Environmental context-supply chain partners' } \\
\text { willingness and capabilities Pressure from } \\
\text { competitors, government assistance, and consumer } \\
\text { preparedness. }\end{array}$ \\
\hline 27 & 2017 & $\begin{array}{l}\text { (Darsinouei \& } \\
\text { Kaukab, 2017) }\end{array}$ & $\begin{array}{l}\text { The following are some of the most prevalent } \\
\text { difficulties: } \\
\text { TOE- Infrastructure impediments } \\
\text { RBV- Factors of cost, Factors of security, and trust } \\
\text { DOI- Obstacles to logistics, The digital knowledge } \\
\text { gap. }\end{array}$ \\
\hline 28 & 2017 & $\begin{array}{l}\text { (Pascucci, } \\
\text { Gigliarano, \& } \\
\text { Gregori, 2017) }\end{array}$ & $\begin{array}{l}\text { SMEs make minimal use of internet technologies. } \\
\text { In terms of internet usage, micro-enterprises fall } \\
\text { behind small businesses. The adoption of the internet } \\
\text { varies by economic sector. The size of the company } \\
\text { is a significant element in deciding whether or not } \\
\text { the internet is used as a management tool. }\end{array}$ \\
\hline 29 & 2017 & (Mbuyisa, 2017) & $\begin{array}{l}\text { The following were identified as obstacles to ICT } \\
\text { usage in the study: } \\
\text { Usage complexity, Expensive hardware, and } \\
\text { connection, Inadequate digital literacy } \\
\text { An unreliable communication networks. }\end{array}$ \\
\hline 30 & 2017 & (AYER, 2017) & $\begin{array}{l}\text { Many Indian SMEs do not desire to grow into } \\
\text { middle-sized businesses and so show no evidence of }\end{array}$ \\
\hline
\end{tabular}




\begin{tabular}{|c|c|c|c|}
\hline & & & $\begin{array}{l}\text { change or development. The causes might be linked } \\
\text { to MSME firms' fear of being watched, non- } \\
\text { compliance, and lack of governance, many of which } \\
\text { are unregistered and conduct cash transactions to } \\
\text { evade correct tax payments. }\end{array}$ \\
\hline 31 & 2017 & $\begin{array}{l}\text { (Darsinouei \& } \\
\text { Kaukab, 2017) }\end{array}$ & $\begin{array}{l}\text { Some of the most prevalent issues are as follows: } \\
\text { Infrastructure constraints, Cost factors, Logistics } \\
\text { barriers, Digital knowledge gap. }\end{array}$ \\
\hline 32 & 2017 & $\begin{array}{l}\text { (Domadenik, } \\
\text { Koman, \& Redek, } \\
\text { 2018) }\end{array}$ & $\begin{array}{l}\text { TOE- (Technological, Organizational, } \\
\text { Environmental) are the Factors Influencing } \\
\text { Technology Adoption. }\end{array}$ \\
\hline 33 & 2018 & $\begin{array}{l}\text { (Domadenik, } \\
\text { Koman, \& Redek, } \\
\text { 2018) }\end{array}$ & $\begin{array}{l}\text { The following factors significantly limit the capacity } \\
\text { of micro, small, and medium-sized businesses to } \\
\text { engage in digital marketplaces: } \\
\text { Inadequate infrastructure, inadequate scalability } \\
\text { Cross-border marketplaces are fragmented. }\end{array}$ \\
\hline 34 & 2018 & $\begin{array}{l}\text { (Nazir \& Zhu, } \\
\text { 2018) }\end{array}$ & $\begin{array}{l}\text { "According to the author, the following are key } \\
\text { considerations in the adoption of e-commerce by all } \\
\text { four SMEs: } \\
\text { Slow Internet speed, Electricity shortages, Limited } \\
\text { financial budget; Lack of ICT infrastructure, Higher } \\
\text { maintenance expenses, Lack of social awareness, } \\
\text { Lack of local government assistance, and poor } \\
\text { government policies, Inadequate tariff rates, } \\
\text { Absence of online payment options, Owner-manager } \\
\text { traits; a lack of entrepreneurship, Lack of } \\
\text { understanding about innovation, Lack of passion and } \\
\text { a lack of managerial education.” }\end{array}$ \\
\hline 35 & 2019 & $\begin{array}{l}\text { (Purwandari, } \\
\text { Otmen, \& } \\
\text { Kumaralalita, } \\
\text { 2019) }\end{array}$ & $\begin{array}{l}\text { All of this has an impact on SMEs' use of e- } \\
\text { marketplaces and influences Instagram adoption in } \\
\text { Indonesia. }\end{array}$ \\
\hline
\end{tabular}




\begin{tabular}{|c|c|c|c|}
\hline & & & $\begin{array}{l}\text { Top Management Approval, Pressure from } \\
\text { Competitors, Financial resources, Risk Perception, } \\
\text { Top management backing, Competitive rivalry, } \\
\text { Benefit as perceived, Vendor assistance. }\end{array}$ \\
\hline 36 & 2019 & $\begin{array}{l}\text { (Kosasi, Kasma, } \\
\text { Vedyanto, \& } \\
\text { Susilo, 2019) }\end{array}$ & $\begin{array}{l}\text { The majority of SMEs in West Kalimantan faced the } \\
\text { following problems, according to the circumstances: } \\
\text { Problems with technology. There is no IT } \\
\text { preparedness. There is no configuration } \\
\text { appropriateness, unreliable internet connections. } \\
\text { Problems with online purchases. There is no internet } \\
\text { access. }\end{array}$ \\
\hline 37 & 2020 & $\begin{array}{l}\text { (Verma \& Shaiba, } \\
\text { 2020) }\end{array}$ & $\begin{array}{l}\text { According to the report, SMEs are frequently } \\
\text { confronted with internal and external challenges in } \\
\text { terms of growth and development since they are small } \\
\text { in size and operated by people or families. } \\
\text { Internal difficulties that SME owners confront } \\
\text { include a lack of qualified people, a lack of competent } \\
\text { personnel, a lack of cash, a lack of competencies } \\
\text { necessary to embrace ICT, and a lack of innovation. } \\
\text { External obstacles that impede the growth of SMEs } \\
\text { include macroeconomic concerns, changing demand, } \\
\text { political issues, and export issues. }\end{array}$ \\
\hline 38 & 2020 & $\begin{array}{l}\text { (Wahyuni, } \\
\text { Widodo, Zulianto, } \\
\text { \& Islami, 2020) }\end{array}$ & $\begin{array}{l}\text { The following are the obstacles that prevent micro and } \\
\text { small businesses from adopting technology and } \\
\text { growing: } \\
\text { Lack of Capital and technology, Market access, } \\
\text { Restricted management, External effects, } \\
\text { Monopolistic tactics. }\end{array}$ \\
\hline 39 & 2020 & $\begin{array}{l}\text { (Anas, Panjaitan, } \\
\text { \& Yean, 2020) }\end{array}$ & $\begin{array}{l}\text { The following are four hurdles to e-commerce } \\
\text { adoption: } \\
\text { Organizational or internal motivations, } \\
\text { Environmental considerations, Factors of } \\
\text { Technology, CEO/owner/senior manager viewpoints }\end{array}$ \\
\hline
\end{tabular}




\begin{tabular}{|l|l|l|l|}
\hline 40 & $\begin{array}{l}\text { (Asmat, Kumar, } \\
\text { Syed, \& Shaikh, } \\
\text { 2021) }\end{array}$ & $\begin{array}{l}\text { Managers encounter a range of hurdles and } \\
\text { roadblocks when it comes to technology adoption, } \\
\text { according to the authors, including Data security, high } \\
\text { infrastructure costs, training expenses, Adoption } \\
\text { problems, administrative difficulties, Organizational } \\
\text { difficulties, problems with attitude, high } \\
\text { infrastructure costs, a lack of technical skills and } \\
\text { efficiency, a lack of government help, a lack of } \\
\text { organizational support. }\end{array}$ \\
\hline
\end{tabular}

Source: Author's own

Holistic Analysis and Discussion

Table 2

\begin{tabular}{|l|l|l|}
\hline Common Challenges & Authors & Frequency \\
\hline $\begin{array}{l}\text { Lack of Unique resources } \\
\text { and capabilities }\end{array}$ & $\begin{array}{l}\text { (Good, 2011), (Ghobakhloo, 2011), (Bin, } \\
\text { Yongyi, \& Lei, 2012), (Bin, Yongyi, \& Lei, } \\
\text { 2012), (Mwangi \& Mwakaba, 2012), (Banerjee, } \\
\text { Wei, \& and Ma, 2012), } \\
\text { (Eze, Duan, \& Chen, 2012), } \\
\text { (OP, 2013), (Kamal, 2013), (A.P \& C.T, } \\
\text { 2013), (Alzahrani, 2013), (Larreina, 2013) } \\
\text { (Juhi \& Maryann, 2014), (M.E \& J.P, Drivers } \\
\text { and inhibitors to e-Commerce adoption among } \\
\text { SMEs in Nigeria, 2014), (D.O, 2014), (Lin, } \\
\text { Understanding the determinants of electronic } \\
\text { supply chain management system adoption: } \\
\text { Using the technology-organization- } \\
\text { environment framework., 2014), (Pendse, } \\
\text { 2015), (Saha, 2015), (Mbinda, 2015), (Pendse, } \\
\text { 2015), } \\
\text { (Ahmad \& Sinha, 2016), (Hussein \& } \\
\text { Baharudin, 2016), (Abualrob, 2016), } \\
\text { (Chatzoglou, Fragidis, Chatzoudes, \& } \\
\text { Symeonidis, 2016), (Darsinouei \& Kaukab, } \\
\text { 2017), (Pascucci, Gigliarano, \& Gregori, } \\
\text { 2017), (AYER, 2017), (Darsinouei \& Kaukab, } \\
\text { 2017), (Pascucci, Gigliarano, \& Gregori, } \\
\text { 2017), }\end{array}$ \\
\hline
\end{tabular}




\begin{tabular}{|c|c|c|}
\hline & $\begin{array}{l}\text { (Domadenik, Koman, \& Redek, 2018), } \\
\text { (Kosasi, Kasma, Vedyanto, \& Susilo, 2019), } \\
\text { (Verma \& Shaiba, 2020), (Anas, Panjaitan, \& } \\
\text { Yean, 2020), (Asmat, Kumar, Syed, \& } \\
\text { Shaikh, 2021). }\end{array}$ & \\
\hline $\begin{array}{l}\text { Lack of IT acquaintance for } \\
\text { e-business implementation }\end{array}$ & $\begin{array}{l}\text { (Good, 2011), (Ghobakhloo, 2011), } \\
\text { (Bélanger, 2011), (Mwangi \& Mwakaba, } \\
\text { 2012), (Banerjee, Wei, \& and Ma, 2012), (Eze, } \\
\text { Duan, \& Chen, 2012) , (Zaied, 2012), (Kamal, } \\
\text { 2013), (Alzahrani, 2013), (Larreina, 2013), } \\
\text { (M.E \& J.P, Drivers and inhibitors to e- } \\
\text { Commerce adoption among SMEs in Nigeria, } \\
\text { 2014), } \\
\text { (D.O, 2014), (Pendse, 2015), (Pendse, 2015), } \\
\text { (Saha, 2015), (Mbinda, 2015), (M.E \& J.P, } \\
\text { 2015), (Pendse, 2015), (Ahmad \& Sinha, } \\
\text { 2016), (Hussein \& Baharudin, 2016), } \\
\text { (Abualrob, 2016), (Chatzoglou, Fragidis, } \\
\text { Chatzoudes, \& Symeonidis, 2016), } \\
\text { (Darsinouei \& Kaukab, 2017), (Pascucci, } \\
\text { Gigliarano, \& Gregori, 2017), (Mbuyisa, } \\
\text { 2017), (Darsinouei \& Kaukab, 2017), (Hsu \& } \\
\text { W, 2017), } \\
\text { (Nazir \& Zhu, 2018), } \\
\text { (Purwandari, Otmen, \& Kumaralalita, 2019), } \\
\text { (Kosasi, Kasma, Vedyanto, \& Susilo, 2019), } \\
\text { (Verma \& Shaiba, 2020), (Wahyuni, Widodo, } \\
\text { Zulianto, \& Islami, 2020), (Anas, Panjaitan, \& } \\
\text { Yean, 2020), (Asmat, Kumar, Syed, \& Shaikh, } \\
\text { 2021). }\end{array}$ & 33 \\
\hline E-commerce Adoption cost & $\begin{array}{l}\text { (Good, 2011), (Zaied, 2012), (OP, 2013), } \\
\text { (Kamal, 2013), (A.P \& C.T, 2013), } \\
\text { (Alzahrani, 2013), } \\
\text { (Juhi \& Maryann, 2014), (M.E \& J.P, Drivers } \\
\text { and inhibitors to e-Commerce adoption } \\
\text { among SMEs in Nigeria, 2014), (D.O, 2014), } \\
\text { (Lin, Understanding the determinants of } \\
\text { electronic supply chain management system } \\
\text { adoption: Using the technology-organization- } \\
\text { environment framework., 2014), (Pendse, }\end{array}$ & 26 \\
\hline
\end{tabular}




\begin{tabular}{|c|c|c|}
\hline & $\begin{array}{l}\text { 2015), (Saha, 2015), (Mbinda, 2015), (M.E \& } \\
\text { J.P, 2015), (Pendse, 2015), (Ahmad \& Sinha, } \\
\text { 2016), (Hussein \& Baharudin, 2016), } \\
\text { (Chatzoglou, Fragidis, Chatzoudes, \& } \\
\text { Symeonidis, 2016) , (Darsinouei \& Kaukab, } \\
\text { 2017), (Mbuyisa, 2017), (Mbuyisa, 2017), } \\
\text { (Darsinouei \& Kaukab, 2017), (Nazir \& Zhu, } \\
\text { 2018), (Purwandari, Otmen, \& Kumaralalita, } \\
\text { 2019), (Wahyuni, Widodo, Zulianto, \& } \\
\text { Islami, 2020), (Asmat, Kumar, Syed, \& } \\
\text { Shaikh, 2021). }\end{array}$ & \\
\hline $\begin{array}{l}\text { Lack of top management } \\
\text { support }\end{array}$ & $\begin{array}{l}\text { (Ghobakhloo, 2011), (Banerjee, Wei, \& and Ma, } \\
\text { 2012), (Eze, Duan, \& Chen, 2012), (Zaied, } \\
\text { 2012), (Juhi \& Maryann, 2014), (M.E \& J.P, } \\
\text { Drivers and inhibitors to e-Commerce } \\
\text { adoption among SMEs in Nigeria, 2014), } \\
\text { (Lin, Understanding the determinants of } \\
\text { electronic supply chain management system } \\
\text { adoption: Using the technology-organization- } \\
\text { environment framework., 2014), (Saha, } \\
\text { 2015), (M.E \& J.P, 2015), (Hussein \& } \\
\text { Baharudin, 2016), (Abualrob, 2016), } \\
\text { (Chatzoglou, Fragidis, Chatzoudes, \& } \\
\text { Symeonidis, 2016), (Mbuyisa, 2017), (AYER, } \\
\text { 2017), (Nazir \& Zhu, 2018), (Purwandari, } \\
\text { Otmen, \& Kumaralalita, 2019), (Verma \& } \\
\text { Shaiba, 2020), (Wahyuni, Widodo, Zulianto, } \\
\text { \& Islami, 2020), (Anas, Panjaitan, \& Yean, } \\
\text { 2020), (Asmat, Kumar, Syed, \& Shaikh, } \\
\text { 2021). }\end{array}$ & 21 \\
\hline \multirow[t]{2}{*}{$\begin{array}{l}\text { Lack of Government } \\
\text { Support }\end{array}$} & $\begin{array}{l}\text { (Mwangi \& Mwakaba, 2012), (Zaied, 2012), } \\
\text { (OP, 2013), (A.P \& C.T, 2013), (Juhi \& } \\
\text { Maryann, 2014), (Mbinda, 2015), (Abualrob, } \\
\text { 2016), (Chatzoglou, Fragidis, Chatzoudes, \& } \\
\text { Symeonidis, 2016), } \\
\text { (AYER, 2017), (Nazir \& Zhu, 2018), (Verma } \\
\text { \& Shaiba, 2020), (Asmat, Kumar, Syed, \& } \\
\text { Shaikh, 2021). }\end{array}$ & 13 \\
\hline & $\begin{array}{l}\text { (Mwangi \& Mwakaba, 2012), (Eze, Duan, \& } \\
\text { Chen, 2012), (Zaied, 2012), (OP, 2013), (A.P }\end{array}$ & \\
\hline
\end{tabular}




\begin{tabular}{|l|l|c|}
\hline Competitive Pressure & $\begin{array}{l}\text { \& C.T, 2013), (Lin, Understanding the } \\
\text { determinants of electronic supply chain } \\
\text { management system adoption: Using the } \\
\text { technology-organization-environment } \\
\text { framework., 2014), (Hussein \& Baharudin, } \\
\text { 2016), (Abualrob, 2016), (Chatzoglou, } \\
\text { Fragidis, Chatzoudes, \& Symeonidis, 2016), } \\
\text { (Domadenik, Koman, \& Redek, 2018), } \\
\text { (Purwandari, Otmen, \& Kumaralalita, 2019), } \\
\text { (Wahyuni, Widodo, Zulianto, \& Islami, } \\
\text { 2020), }\end{array}$ & \\
& & \\
\end{tabular}

Source: Authors Own

\section{RESULTS}

According to a holistic review of the literature over the last decade with specific reference to RBV, DOI, and TOE theories, and below mentioned challenges were uncovered and considered to be more prevalent in SMEs while implementing E-commerce for I4.0 sustainability, a lack of unique resources and capabilities, a dearth of IT acquaintance for e-business implementation, the cost of E-commerce adoption, top management support, government support, and competitive pressure.

\section{- Resource-Based View (RBV)}

0 Lack of unique resources and capabilities

\section{- Diffusion Of Innovation (DOI)}

\section{o Innovation Characteristics}

o Lack of IT acquaintance for e-business implementation

- Technology- Organization-Environment (TOE)

\section{o Organisational Factors}

- E-commerce Adoption cost

- Top management support

o Environmental Factors

- Government Support

- Competitive Pressure

The proposed study linked the adoption of e-commerce innovation to the notable performance of SMEs. The TOE model's two valuable components were adequately incorporated. As a satisfactory result, the initial contribution was the efficient implementation in consonance with the TOE model and advanced technologies utilization (DOI theory), namely the successful mediation of e-commerce use. The comprehensive study reveals precisely that two parts of the TOE model, namely the organizational and environmental context variables, are undoubtedly required for technological implementation. The study also established a methodological approach for small and medium enterprises based on the resource-based perspective (RBV). 


\section{Lack of unique resources and capabilities}

As per the proposed systematic literature review analysis (SLRA) 35 published articles out of 40 selected articles, the first fundamental premise is that organizations' essential competencies, creative potentials, and other experts should differ appreciably from each other's. If officialdoms had a similar level and composition of resources, they couldn't employ diverse methods to battle with one another. What one company achieves, the other may merely copy, and no competitive edge can be gained. This is a perfect competition situation, but traditional markets have been far from perfect, and some enterprises subjected to certain fierce competitive pressure (same external conditions) can deploy strategic options and surpass one another.

As an ultimate result, Research has reasonably estimated that enterprises realistically achieve a sustainable competitive advantage by utilizing their various resource multipacks. The RBV model emphasizes the paramount importance of valuable resources in assisting lucrative businesses to attain improved organizational effectiveness.

\section{Lack of IT acquaintance for e-business implementation}

According to holistic SLRA (33/40), the second most significant factor is IT knowledge and the findings indicate that employing a sustainable innovation approach with an extensive understanding of information systems (IS) with the usage of e-commerce forums can encourage a corporation. Preliminary research on e-business deployment in developing nations incorporated insights from both emerging and established enterprises. (Dewan \& and Kraemer, 2000) discovered, for notable example, that emerging and advanced countries differ tremendously concerning the appreciable extent of IT implementations and the contributing aspects which positively influence its applications. Security concerns are critical in IT, particularly in e-commerce (Larreina, 2013).

A violation of guaranteed security undoubtedly occurs when a firm or government entity ends up losing relevant data, private information, or other subtle documents. Safety and confidentiality concerns are a fundamental hurdle to e-commerce. The proposed research considered security as a prime concern and it is precisely corresponding to how trustworthy an internet platform is for transferring sensitive facts and controlling online transactions. First, as a matter of fact of the use of multiple direct regulations in the sphere of Internet technology, there's much less control over records.

As a result, sustainable businesses and their informed consumers may be more concerned about unwanted data access, which could credibly threaten data safety and confidentiality. Second, E-business is seamlessly incorporated in business deals, involving the transfer of necessary funds along the value chain. If successful enterprises engaging in online transactions have safety issues, their active involvement in electronic-business activities should be carefully scrutinized.

\section{E-commerce adoption cost}

However, the current study analysis sufficiently indicates that there is little support for the profound effect of adaptation cost on e-commerce use. In addition, cost remains one of the most significant hurdles to technology adoption. Furthermore, the cost of adaptation has no effect on the depletion of E-commerce in SMEs. According to the earlier literature survey, open innovation involves collaborating and supporting underused assets with other businesses. Similarly, with open innovation applications most of the SME's shift to a contract rate, such as third-party cloud services. Furthermore, subscribing to these e-commerce sites is simple and inexpensive. As a result of SLRA 26/40 published articles out of 40 research papers, the cost of implementation appears third most determining factor in the use of E-commerce in SMEs.

\section{Top Management support}

The top management is in charge of efficiently allocating the necessary funds and valuable resources required to usage electronic commerce. The excitement and aid of senior management 
for strategic cooperation and alliances with international firms are associated with the effectiveness of open innovation implementation. Furthermore, open innovation necessitates inter-and cross-functional and cross-collaboration; hence, SMEs must maintain persistent administration aids and abilities to enable open innovation and profitability ratios.

The key findings show that "top management support (TMS)" and "competitive pressure (CP)" engage in a substantial influence in SMEs' use of e-commerce, and these outcomes are coherent with initial studies. As an ultimate result, the present study analyses E-commerce as a premeditated choice to positively enhance the operational effectiveness of SMEs.

\section{Government support}

Furthermore, the influence of government assistance (GS) on the acceptance of E-commerce is inconsiderable in the current study. Because the governments of emerging economies urge and support the use of e-commerce for massive enterprises in the three methods listed below. First, by giving incentives; second, by enacting specified rules and necessary legislation; and devoted third, by adequately developing talented personnel and establishing IT facilities. According to the research, SMEs cannot undertake open innovation to commercialize their business to the international market without the help of the government. In comparison to huge corporations, SMEs necessitate suitable government policies and support, such as tax breaks, regulatory frameworks to ensure security and scam, and electronic-commerce platforms to boost open innovation in industrial Enterprises.

\section{Competitive Pressure}

Furthermore, agreeing to RBV theory, asserted the considerable importance of successful enterprises undoubtedly having distinctive resources and essential competencies to contribute positively to industry rivalry to gain a competitive edge. Much research on technology-enabled innovation and company performance has revealed excellent results. Furthermore, organizations might gain a competitive vantage if they pool their resources and competencies to make it challenging for entrants to replicate them. Additionally, some successful businesses are focusing on a full open innovation strategy. Most, on the other hand, thrive on continuous development. Though, open innovation, like E-commerce, remains a nonstop cycle that can be used to obtain a competitive edge.

\section{Findings (Proposed)}

According to the intriguing findings, "ERP-enabled enterprises and non-ERP-enabled" organizations are confronting specific challenges like "lack of unique resources and capabilities, lack of IT knowledge for E-commerce adaptation, top management support, government resource assistance, and government regulatory support” to efficiently implement E-business. The investigative findings adequately provide a variety of prevailing views for executives in "ERP-enabled and non-ERP-enabled" enterprises, the E-commerce industry, ERP providers, government, established professionals in the production, distribution, and service sectors. Furthermore, the considerable intended and unintended association with the efficient utilization of e-commerce requires SME managers should pay attention to the provision of illustrated resources before adopting E-commerce in their firms. The significance of the study is to support SMEs to realistically achieve an ultimate result to achieve long-term sustainability.

\section{CONCLUSION}

The comprehensive study's investigative findings provide insights into administrative and environmental aspects through the unintended relationship of E-commerce adoption to positively enhance the potential productivity of SMEs. The empirical analysis amply demonstrates that organizational support and intense competition undoubtedly have a persuasive direct and indirect influence on the performance when using e-commerce as an effective medium. However, the cost of adaptation and government backing do not consider to be substantial when it comes to e-commerce implementations. 
The practice of implementing the use of E-commerce in the present new digital era is essential as time progresses. This exploratory study is significant for E-commerce implementation because it is focused on technological and environmental unique phases in the setting of construction companies. Soon, the effective deployment of e-commerce will achieve a considerable increase in the remarkable success of small and medium SMEs. The current study contributes by giving valuable advice to legislators, government agencies, and executive management. These organizations have achieved a successful effort to undoubtedly encourage the efficient implementation of e-commerce incorporation in manufacturing SMEs.

Before implementing e-commerce, scientific scholars and successful practitioners should adequately consider foundational resources and necessary expertise associated with organizational and ecological elements, according to the conclusions of the study. Furthermore, rather than encouraging firms to embrace e-commerce solely while some market participants have been doing so, the present study concludes that organizations ought to decide on a concrete goal before selecting to practice E-commerce. It should be consistent with the company's ultimate purposes and key priorities

\section{Limitations and Future Research Directions}

The current study is merely valuable to SME businesses in emerging economies because it focuses primarily on business enterprises. To boost the extensive research's universal applicability, the study should have been conducted through manufacturing SMEs in underdeveloped nations across the world. Research progress should also meet the speculative underpinning of vibrant philosophy by taking overt and covert active resources into account to gain a competitive vantage.

The present study also has certain limitations, but there are interesting opportunities for subsequent research. The authors of this study comprehensively examined specific hurdles in the effective implementation of E-commerce in SMEs. This study is geographically unrestricted; nevertheless, aspiring researchers can carefully collect primary data from a specified geographic area and then analyse the information to determine whether the identical impediments would emerge as between the most significant barriers in user acceptance or not. Other challenges may exist that haven't even been addressed.

\section{Implications for Business Managers}

Nonetheless, relatively few researchers have adequately tested the ideas of the TOE, DOI, and $\mathrm{RBV}$ in conjunction. Furthermore, the comprehensive study contributes by satisfactorily addressing the profound significance of electronic-commerce as a moderating variable between essential TOE characteristics and company success. The gradual incorporation and effective use of electronic commerce are critical to progressively increasing overall effectiveness in the digital realm. This study has successful applicability since it employs the "TOE model”, which is appropriate for the implementation of E-commerce and, as a result, adds to the enhanced performance of small and medium-sized organizations.

Furthermore, the considerable active and passive relationship with the consistent practice of E-commerce undoubtedly requires competent SME managers to pay attention to the accessibility of such valuable assets before deploying E-commerce in respective firms. As the desired result, this comprehensive study attempted to adequately describe the critical underlying characteristics and unique capabilities required to transition the organization from traditional business methods to click-and-mortar via electronic-commerce.

\section{Acknowledgement}

The paper was presented at the AICTE International Conference on Circular Economy, Management and Industry, Bharati Vidyapeeth's Institute of Management Studies and Research, Navi Mumbai, and Apeejay School of Management, Dwarka, Delhi, India. October 2021. 


\section{References}

Shemi, A. P, \& Procter, C. T. (2013). Challenges of e-commerce adoption in SMEs. An interpretive case study of Botswana.

Abualrob, A. A. (2016). The barriers that hinder the adoption of e-commerce by small businesses: Unique hindrance in Palestine. Information Development, 1528-1544.

Ahmad, I., \& Sinha, J. (2016). E-Commerce: Adoption barriers in small and medium-sized enterprises (SMEs) in India. SMS J. Entrep. Innov, 2(2), 48-53.

Alzahrani, S. (2013). Saudi Female Entrepreneurs: Business Motivations and Commitment to Solving Women's Social Issues. International Textile and Apparel Association Annual Conference Proceedings. Iowa State: University Digital Press.

Anas, T., Panjaitan, N. A., \& Yean, T. S. (2020). E-Commerce in Indonesia: What is Holding Back Small Businesses? ISEAS - Yusof Ishak Institute Analyse Current Events.

ASEAN. SME Policy Index; OECD/ERIA: Jakarta. ( 2020, 3 November). doi:https://doi.org/10.1787/

(2018). Asia Pacific Economic Coorporation Report. Belgien: Economic Committee(EC): Bruxelles.

Asmat, S., \& Mohd, Z. S. (2021). A Viewpoint On Sustainable Practices Of Coles And Woolworths During COVID-19. Academy of Marketing Studies Journal Volume 25, Special Issue 2, 2021, 25(2).

Asmat, S., Anuj, K., Asif, S., \& Zafar, S. (2021). A Two-Decade Literature Review On Challenges Faced By Smes In Technology Adoption. Academy Of Marketing Studies , 25(3).

Asmat, S., Kumar, A., Syed, A. A., \& Shaikh, M. Z. (2021). A Two-Decade Literature Review on Challenges Faced by SMEs in Technology Adoption. Academy of Marketing Studies Journal, 25(3).

Asmat, S., Mohd, Z. S., \& Anuj, K. (2021). Empirical study: Influence of trade value offered by e-marketers on intention quotient of Mumbai based online shoppers to shop online. Journal of Contemporary Issues in Business and Government, 27(2). doi:DOI: 10.47750/cibg.2021.27.02.566

Ayedee, N., Anuj, K., \& Asmat, S. (2021). Role Of Emotional Intelligence And Strategic Human Resource Management During COVID-19 PANDEMIC. Academy of Strategic Management Journal , 20(special issue, 5).

Ayer, R. R. (2017). Adaptation of E-Commerce Channel by MSME in India. International Journal of Business and General Management (IJBGM), 6(6), 11-28.

Banerjee, P., Wei, K., \& and Ma, L. (2012). Role of trialability in B2B e-business adoption: theoretical insights from two case studies. Behaviour \& Information Technology, 31(9), 815827.

Bélanger, F. (2011). Privacy in the digital age: a review of information privacy research in information systems. MIS quarterly, 1017-1041.

Bin, G., Yongyi, S., \& Lei, X. (2012). Industrial clusters and regional inclusive development: Experience from China. IEEE International Conference on Management of Innovation \& Technology (ICMIT), 123-128.

Chatzoglou, P., Fragidis, L., Chatzoudes, D., \& Symeonidis, S. (2016). Critical success factors for ERP implementation in SMEs. Federated Conference on Computer Science and Information Systems (FedCSIS) (pp. 1243-1252). IEEE.

Faloye, D. O. (2014). The adoption of e-commerce in small businesses: An empirical evidence from retail sector in Nigeria. Journal of Business and Retail Management Research, 8(2). 
Darsinouei, A. E., \& Kaukab, R. S. (2017). Understanding E-Commerce Issues in Trade Agreements. Cuts International, Geneva.

Depietro, R., Wiarda, E., \& Fleischer, M. (1990). The context for change: Organization, technology and environment. Technol. Innov., 151-175.

Dewan, S., \& and Kraemer, K. (2000). Information technology and productivity: evidence from country-level data. Management science, 46(4), pp., 46(4), 548-562.

Domadenik, P., Koman, M., \& Redek, T. (2018). Creating supportive digital environment to promote innovation, increase value added creation and stimulate growth. Shaping the future: opportunities and challenges of e-commerce. Domadenik, Polona.

Domadenik, P., Koman, M., \& Redek, T. (2018). The Role Of E-Commerce For Micro, Small And Medium Enterprises. Shaping The Future: Opportunities And Challenges Of E-Commerce. Časnik Finance, d. o. o, 12.

Dutta, P., Mishra, A., Khandelwal, S., \& and Katthawala, I. (2020). A multiobjective optimization model for sustainable reverse logistics in Indian E-commerce market. Journal of Cleaner Production, 119-348.

Eze, S., Duan, Y., \& Chen, H. (2012). Factors affecting emerging ICT adoption in SMEs: An actor network theory analysis. (pp. 361-377). Springer, Berlin, Heidelberg.

Ghobakhloo, M. (2011). “Adoption of e-commerce applications in SMEs.”. Industrial Management \& Data Systems,, 111(8), 1238-1269.

Good, T. G. (2011). An Investigation of Microenterprise Capability-building via Access and Use of Technology. The Graduate College at the University of Nebraska.

Hsu, C., \& Yeh, C, C. (2017). Understanding the factors affecting the adoption of the Internet of Things. Technology Analysis \& Strategic Management,, 1089-1102.

Hsu, P., Kraemer, K., \& and Dunkle, D. (2006). Determinants of e-business use in US firms. International Journal of Electronic Commerce, 10(4), 9-45.

Hussein, L. A., \& Baharudin, A. S. (2016). Factors affecting the owner's intention/continuance e-commerce adoption in Jordan small and medium enterprises. International Journal of Computer Science and Information Security, 14(11), 75.

Hwang, D., \& and Min, H. (2015). Identifying the drivers of enterprise resource planning and assessing its impacts on supply chain performances. Ind. Manag. Data Syst, 115, 541-569.

Juhi, W., \& Maryann, G. (2014). Challenges of Strategy Implementation faced by micro and small women entrepreneurs in Nakuru County, Kenya. Doctoral dissertation, University of Nairobi.

Kamal, M. (2013). A roadmap for microenterprise growth through Information Technology. International Journal of Management Practice, 6(1), 4-23.

Kosasi, S., Kasma, U., \& Susilo, B. (2019). The mediating role of intention to use e-commerce adoption in MSMEs. In 2019 1st International Conference on Cybernetics and Intelligent System (ICORIS), 1, 29-34.

Larreina, J. G. (2013). Smart manufacturing execution system (SMES): The possibilities of evaluating the sustainability of a production process. 11th Global Conference on Sustainable Manufacturing, GCSM 2013: Innovative Solutions (pp. 517-522). ETH Zürich.

Lin, H. (2014). Understanding the determinants of electronic supply chain management system adoption: Using the technology-organization-environment framework. Technological Forecasting and Social Change, 86, 80-92.

Lin, H., \& Lin, S. (2008). Determinants of e-business diffusion: A test of the technology diffusion perspective. Technovation, 28(3), 135-145. 
SLRA: Challenges faced by SMEs in the adoption of E-commerce and sustainability in Industry 4.0.

Lu, S., Yang, L., Liu, W., \& Jia, L. (2020). User preference for electronic commerce overpackaging solutions: Implications for cleaner production. Journal of Cleaner Production, 258.

Agwu, M. E.., \& Murray, J. P. (2014). Drivers and inhibitors to e-Commerce adoption among SMEs in Nigeria. Journal of Emerging Trends in Computing and Information Sciences, 5(3), 192-199.

Agwu, M. E. \& Murray, J. P. (2015). Empirical study of barriers to electronic commerce adoption by small and medium scale businesses in Nigeria. International Journal of Innovation in the Digital Economy, 6(2), 1-19.

Mata, F., Fuerst, W., \& Barney, J. (1995). Information technology and sustained competitive advantage: A resource-based analysis. MIS quarterly, 487-505.

Mbinda, B. (2015). Constraints facing small medium and micro enterprises in Khayelitsha, Western Cape. Doctoral dissertation, Cape Peninsula University of Technology.

Mbuyisa, B. B. (2017). ICT Usage in Small, Medium and Micro Enterprises: A South African Perspective Of its Role and Impact on Poverty Reduction. Doctoral dissertation, University of Pretoria.

Mwangi, M. M., \& Mwakaba, N. I. (2012). Taking micro-enterprise online: the case of kenyan businesses. In CHI'12 Extended Abstracts on Human Factors in Computing Systems, 367-382.

Nazir, A. M., \& Zhu, X. D. (2018). E-commerce adoption factors affecting the SMEs: A case study investigation of a developing economy. In British Academy of Management Conference September.

Odhiambo, O. (2013). E-commerce adoption among micro, small and medium sector in Nairobi County, Kenya. Doctoral dissertation, Kenyatta University.

Ozturk, A. (2016). Customer acceptance of cashless payment systems in the hospitality industry. International Journal of Contemporary Hospitality Management., 28, 801-817.

Pascucci, F., Cardinali, S., Gigliarano, C., \& Gregori, G. L. (2017). Internet adoption and usage: evidence from Italian micro enterprises. International Journal of Entrepreneurship and Small Business,, 259-280.

Pascucci, F., Gigliarano, C., \& Gregori, G. L. (2017). Internet adoption and usage: evidence from Italian micro enterprises. International Journal of Entrepreneurship and Small Business, 30(2), 259-280.

Paul, J., \& Bhukya, R. (2021). A bibliometric review and directions for future research. International Journal of Consumer Studies,, 45(5), 937-963.

Pendse, P. D. (2015). Information technology as an Business Enabler in MSMEs in India. Tirpude's National Journal of Business Research, 5(1).

Purwandari, B., Otmen, B., \& Kumaralalita, L. (2019). Adoption factors of e-marketplace and instagram for micro, small, and medium enterprises (MSMEs) in Indonesia. In Proceedings of the 2019 2nd International Conference on Data Science and Information Technology, 111-116.

Rothaermel, F. T. (2013). Strat.Mgmt.: Concepts and Cases. McGraw-Hill/Irwin.

Saha, B. (2015). E-Commerce Adoption by Micro Small and Medium Sized Enterprises of Bangladesh. International Journal of Management (IJM), 6(3), 106-116.

Snyder, H. (2019). Literature review as a research methodology: An overview and guidelines. Journal of business research(104), 333-339.

Verma, E. D., \& Shaiba. (2020). Study on Challenges Faced in Adoption of Internet Marketing and E-Commerce by Indian Msmes. JournalNX, 6(12), 72-79. 
Wahyuni, S., Widodo, J., Zulianto, M., \& Islami, N. N. (2020). The analysis of e-commerce utilization in Micro, Small and Medium Enterprises (MSMEs) at Jember. IOP Conference Series: Earth and Environmental Science, 485(1), 012037.

Zafar, A., \& and Mustafa, S. (2017). SMEs and its role in economic and socio-economic development of Pakistan. nternational Journal of Academic Research in Accounting, Finance and Management Sciences, 6(4), 195-205.

Zaied, A. (2012). Barriers to e-commerce adoption in Egyptian SMEs. International Journal of Information Engineering and Electronic Business, 4(3), 9.

Zhu, K., Kraemer, K., \& and Xu, S. (2003). Electronic business adoption by European firms: a cross-country assessment of the facilitators and inhibitors. European journal of information systems, 12(4), pp.251-268., 12(4), 251-268.

Asmat, S., \& Mohd, Z. S. (2021). A viewpoint on sustainable practices of coles and woolworths during COVID-19. Academy of Marketing Studies Journal Volume 25, Special Issue 2, 2021, 25(2).

Asmat, S., Mohd, Z. S., \& Anuj, K. (2021). Empirical study: Influence of trade value offered by e-marketers on intention quotient of Mumbai based online shoppers to shop online. Journal of Contemporary Issues in Business and Government, 27(2). doi:DOI: 10.47750/cibg.2021.27.02.566

Ayedee, N., Kumar, A., \& Shaikh, A. (2021). Role of emotional intelligence and strategic human resource management during COVID-19 pandemic. Academy of Strategic Management Journal , 20(special issue, 5). 